\title{
Investigation and Analysis of the Oral Expression Competency Among Students in Second-tier Universities: Based on China's Standards of English Language Ability
}

\author{
Meifang Jiang ${ }^{*}$, Honghui Zhou ${ }^{2 *}$ \\ ${ }^{1}$ School of Foreign Studies Lingnan Normal University, Zhanjiang, China \\ ${ }^{2}$ School of Foreign Studies, Guangdong University of Finance and Economics, Guangzhou, China \\ *Corresponding authors: Meifang Jiang, jiangmeifang2005@163.com; Honghui Zhou, 10869704@qq.com
}

Copyright: (C) 2022 Author(s). This is an open-access article distributed under the terms of the Creative Commons Attribution License (CC BY 4.0), permitting distribution and reproduction in any medium, provided the original work is cited.

\begin{abstract}
By adopting quantitative analysis, based on the statements for oral scale of CSE (China Standards of English) level five, this paper investigated the current status, common difficulties and control factors on oral English competency of nonEnglish majors in second-tier universities, which was conducted using questionnaires that includes six dimensions of language expression: accuracy, complexity, coherence, fluency, appropriateness, and flexibility. The results showed that: (i) the overall oral English competency of college non-English majors hasn't met the statements of CSE level five; (ii) female students significantly outperformed male students, and business majors students significantly outperformed those in liberal arts majors who were significantly better than those in science majors; (iii) there was no significant difference between grades; (iv) the flexibility, coherence and accuracy of language expression almost reached the standard grade, but the common core difficulties faced by the students were mainly in pronunciation, scope of language expression, fluency and appropriateness. Unclear goals, less practice and poor vocabulary were major impact factors. The research is helpful for strengthening students' knowledge on their own oral English competency as well as adjusting their oral practice objectives, thereby shedding light on students' actual oral English proficiency and helping to clarify and refine the teaching objectives of speaking and promote the effective practice of oral English as well as the rational application of CSE.
\end{abstract}

Keywords: China Standards of English; Non-English majors; College students, Oral English proficiency

Online publication: January 20, 2022

\section{Introduction}

With the rapid development of economy, the oral language proficiency among college graduates has constantly been a concern of the society. In 2018, China's Standards of English Language Ability (CSE) was issued, which takes application of the language as the primary goal of language learning and puts oral expression ability into assessment. Chinese learners' English competence in the CSE is classified into three stages and nine levels. Level 5 and level 6 correspond to non-English major college students (NEMCS), which are roughly equivalent to the primary and intermediate requirements of College English Curriculum Requirements (Requirements) ${ }^{[1,2]}$. The CSE lays emphasis on science, practicality and operation ${ }^{[3]}$, which is a yardstick to measure English ability of domestic students as well as an instruction for English teaching ${ }^{[4]}$. The speaking scale of China's Standards of English Language Ability (CSE-SS) gives a reference not 
only for oral English teaching, but also an assessment at various stages in China. Current research of CSESS mainly focuses on four aspects: discussion on principles and methods of the scale construction ${ }^{[5]}$; exploration on "can-do" descriptors ${ }^{[5-7]}$; research on integration between test and the scale ${ }^{[8]}$; and study of its validity ${ }^{[9]}$ and influence on the test construct validity ${ }^{[10]}$. So far, only few empirical research has been undertaken on the application of language proficiency scales. Using CSE-SS as an example, Jin and Jie discussed the major challenges by its application, proposed a framework and set out a research agenda for the CSE-SS impact studies ${ }^{[2]}$. Based on the CSE-SS, the study is to evaluate the current situation of nonEnglish major college students' oral English competence and explore the characteristics, helping learners' self-assessment and self-reflection of their strengths and weaknesses for oral expression as well as teachers' adjustment on teaching objectives, content and methods, and providing an empirical basis for the future practice and exploration of oral scale.

\section{Literature review}

The study on the process and competence for oral expression has always been greatly concerned in psycholinguistics, cognitive linguistics, second language acquisition and other disciplines ${ }^{[11]}$, and oral expression is regarded as an integral unity as well as a procedural and holistic concept in cognitive vision [12-14]. According to the theory of communicative language competence ${ }^{[15-17]}$, language competence includes the language knowledge mastered by language users and the strategic ability to guide and monitor language communication, and the acquisition of language knowledge and strategy is an important criterion to distinguish speakers of different levels. Bachman defined communicative language competence as "the ability to make proper use of knowledge to communicate in specific situation." ${ }^{[15]}$ Yang et al. defined oral English competence as "the ability to use oral English to communicate and complete communicative tasks in specific occasions." [18]

International research on speaking of Second Language mainly focuses five aspects [19]: (i) Development of phonology; (ii) Learners' ability of listening and speaking and its relationship; (iii) Factors affecting oral learning of second language learners, such as attitude, motivation and social environment; (iv) Transferring of native language from the perspective of language change, variation and marker; and (v) Research on oral English teaching, including learning and thought process, communication strategies, classroom teaching and assessing. Up to now, the above-mentioend five research topics are still the focus, which mainly concentrate on the results of oral expression, rather than analyzing the problems in the development process based on the detailed description of the oral development process of the second language learners. China started late on the study of oral expression of Second language, but has attracted much attention of researchers ${ }^{[20,21]}$, and meanwhile, they began to rethink foreign language education ${ }^{[2]}$. The study of oral expression of second language mainly covers four fields: (i) Establishing the theoretical model of spoken language development; (ii) Research on effective forms of oral English evaluation ${ }^{[23,24]}$;

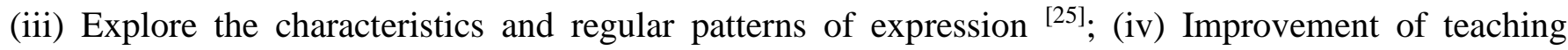
methods ${ }^{[11,26-28]}$. In addition, it has attracted much attention from scholars, such as the development of fluency, accuracy and complexity for oral expression ${ }^{[29,30]}$, communication strategies and Individual differences ${ }^{[31]}$, thinking process of oral expression, controlling factors for oral ability ${ }^{[32-37]}$, etc. However, the objects of the above study were mainly freshmen (majors/non-majors) and middle school students, rarely focusing on sophomores and juniors. Few concerned the learning needs of college students at different levels for oral expression ${ }^{[22]}$. Fewer researches evaluated the current situation and core problems of students' oral proficiency based on CSE, which mostly focus on the fluency, accuracy and complexity of oral expression. Skehan believes that "fluency," "accuracy" and "complexity" are the basic indicators to evaluate oral proficiency ${ }^{[38]}$. Crookes (1989) and Wigglesworth (1997) argue that the validity of communication can be judged by examining the accuracy of grammar use in learners' oral expressions ${ }^{[39,40]}$. 
According to Yang et al., for a comprehensive description of the spoken language ability, it should commence with the accuracy (phonology, grammar), richness (vocabulary, syntax), coherence (use of connection means), fluency (the length of the continuous speech), appropriateness (effective participation) and flexibility (use of communication strategy) ${ }^{[7]}$.

Based on the "can-do" statement for oral Expression of CSE level 5, this study is to explore the current situation of oral English ability of NEMCS from Chinese second-tier universities, discusses the core issues and influencing factors of the development of their oral English ability and analyze the central difficulties and contributing factors, providing suggestions for oral English development of domestic non-English major college students from second-tier universities.

\section{Study}

Before the study, 575 subjects were investigated for their learning behaviors and learning environment. According to the survey, $99.73 \%$ of them have at least one smart phone; $99.46 \%$ have ever used mobile phone apps of English learning; $95.12 \%$ think spoken English is very important; $95.93 \%$ hope to improve their oral expression ability, of which $13.27 \%$ have a short-term experience of speaking English abroad. College students in the new era have more access to the shared resources, with excellent resources and better conditions for oral English learning and practice.

\subsection{Research questions}

Based on SA and the sub-scales for oral expression of the CSE, this study analyzed NEM college students' current status of oral English ability and common difficulties, explored the main factors restricting the development of their oral ability. The study intended to answer the following three questions: (i) What is the current situation on oral English ability of NEM college students? Are there significant differences between genders, grades and majors? (ii) What problems do NEM college students have in their oral English ability? (iii) What are the main factors affecting their development of oral English ability?

\subsection{Participants}

Participants of the study are 575 NEM Chinese students (the second- and third-year) (NEMCS) from second-tier universities (in region of Pearl River Delta, the inland city of Changsha and the western region of Guangdong province), including 133 junior students who have finished all four books learning of College English and 442 sophomores who are learning College English Book III at the time of this study. Students' score of Gaokao is higher than enrollment cut-off point of the university and have been learning English as a second language. Students have participated in self- and peer- assessment and received relevant training and guidance.

\subsection{Research methodology}

The study adopts the methods which mainly include questionnaire and semi-structured interview. The questionnaire is designed based on the "can-do" statements of self-assessment (SA) scale and sub-scales for oral expression of the CSE level 5 without destroying the contents of original descriptors. Studies have shown that self-assessment can effectively acquire the situation of English proficiency of second language learners ${ }^{[41-43]}$. Self-assessment is a reliable and effective way to test students' communicative language competence. Compared with students' own listening and reading abilities, students can more accurately assess their own speaking and writing abilities ${ }^{[4]}$. The questionnaire is composed of two parts. Part One is about the participants' basic information (as shown in Table 1), consisting of gender, major and grade. Part Two is the body of questionnaire, 29 items included which covered six dimensions of features of oral 
expression: accuracy, breadth, fluency, coherence, appropriateness, and flexibility. The study of features for oral expression is of great practical significance for teaching and testing ${ }^{[5]}$. Subjects were asked to tick only one choice on each item on a five-point Likert Scale ranging from one (never true for me) through two (usually not true for me), three (somewhat true for me) and four (usually true for me) to five (always true for me). The self-assessment score was the sum of the responses: the higher the score was, the more accurate the language expression was and the richer the sentence pattern, as well as the more the fluency, the better the coherence, the more appropriate the language, the more the flexibility. It showed the higher the oral expression ability.

Table 1. Basic information of the participants

\begin{tabular}{cccc}
\hline Information & Classification & Total number of people & Percentage \\
\hline \multirow{2}{*}{ Gender } & Male & 152 & $26.43 \%$ \\
& Female & 423 & $73.57 \%$ \\
\hline \multirow{2}{*}{ Major } & Arts & 232 & $40.35 \%$ \\
& Science & 245 & $42.61 \%$ \\
& Business & 98 & $17.04 \%$ \\
\hline Grade & Sophomore & 442 & $76.87 \%$ \\
& Junior & 133 & $23.13 \%$ \\
\hline
\end{tabular}

To have more detailed and accurate results of quantitative analysis, the paper also adopts the method of interview. We randomly selected five students in eight classes out of 16 involved in the survey; there was a total of 40 including sophomores and juniors. The interview focused on three aspects: (i) How about the respondents' attitude towards oral English learning, self-assessment oral English ability and the expectation of improvement? (ii) What are the ways for practice and the practice length per week? (iii) What are the big difficulties in expressing personal views in English?

\subsection{Data collection}

A total of 575 NEM college students were surveyed by online questionnaire on the platform of Wenjuanxing. The link of the questionnaire was forwarded to the students by English teachers in these universities. 575 questionnaires were collected and 422 were valid. SPSS19.0 software was used to conduct descriptive statistics analysis such as $t$-test and analysis of variance (ANOVA).

To test the credibility of the data and ensure the scientific conclusions, the study adopted Cronbach $\alpha$ reliability coefficient and factor load coefficient test to verify the reliability and validity of the questionnaire. From the results of reliability test as shown in Table 2, coefficient values of all six dimension are greater than 0.8 , the minimum value is 0.812 , which could be used for further analysis. The CITC values corresponding to the analytical terms are greater than 0.7 . There is a good correlation between the analysis items. Exploratory factors were used to test validity, 29 items of the questionnaire were classified into six dimensions. The results showed all common values for validity test of all items that are greater than 0.5 , information can be effectively extracted; KMO is $0.970(>0.8)$, Bartlett spherical test results are significant (Sig.=0.000), the value of CPV is $73.370 \%(>50 \%)$. Most item information were extracted for six dimensions, showing that the research data has good structural validity. The result of confirmatory factor analysis proved that the AVE values for each dimension are greater than 0.5 , and CR values all are greater than 0.7 , indicating a good aggregation validity of the data. 
Table 2. Results of reliability test

\begin{tabular}{cccc}
\hline Factor & Number of scales & KMO values & Cronbach's $\alpha$ factor \\
\hline Accuracy of language expression & 7 & $.852^{* *}$ & .875 \\
Complexity of language expression & 4 & $.801^{* *}$ & .857 \\
Coherence of language expression & 4 & $.806^{* *}$ & .825 \\
Fluency in Language Expression & 5 & $.847^{* *}$ & .870 \\
Appropriateness of language expression & 3 & $.802^{* *}$ & .812 \\
Flexibility of language expression & 6 & $.864^{* *}$ & .908 \\
\hline
\end{tabular}

\section{Findings and discussion}

\subsection{The current situation of participants' oral expression ability}

\subsubsection{Participants' overall results of oral expression competency}

The descriptive statistical analysis of the survey results does not contain exception value. The mean value of six dimensions on oral ability (accuracy, scope, coherence, fluency, appropriateness, and flexibility) can be described and analyzed. As stated in Table 3, the mean of each dimension (between 2.498 and 2.931) and the questionnaire (2.762) is lower than the average score (3.0), and the standard deviation is less than one. It shows the subjects' overall level of oral expression competency are in the lower level of the scale and has not yet reached the CSE level 5, but flexibility (2.931), consistency (2.841) and accuracy (2.819) of expression are almost reaching the level. The scores of appropriateness (2.779), fluency (2.705) and scope (2.499) are low, which are still far from the statements of CSE level 5. In particular, the scope of oral expression needed to be improved urgently. The maximum value also indicates that the scope and fluency of the subjects' oral expression are the ability items that need to be paid attention to.

Table 3. Current level of oral expression ability of college non-English majors

\begin{tabular}{ccccccc}
\hline Dimensions & $\begin{array}{c}\text { Number of } \\
\text { items }\end{array}$ & N & Minimum value & Maximum value & Average & Standard deviation \\
\hline Accuracy & 7 & 422 & 1.000 & 4.714 & 2.819 & .658 \\
Breadth & 4 & 422 & 1.000 & 4.500 & 2.498 & .666 \\
Coherence & 4 & 422 & 1.000 & 4.500 & 2.841 & .676 \\
Fluency & 5 & 422 & 1.000 & 4.600 & 2.705 & .691 \\
Appropriateness & 3 & 422 & 1.000 & 5.000 & 2.779 & .735 \\
Flexibility & 6 & 422 & 1.000 & 5.000 & 2.931 & .708 \\
Total & 29 & 422 & 1.000 & 4.719 & 2.762 & .689 \\
\hline
\end{tabular}

\subsubsection{Differences among participants of different genders, grades, and majors}

The data is normally distributed by test, $t$-test can be used to analyze the difference between two sets of data. There is no significant difference $(P>0.05)$ between participants of different genders, grades and majors on the dimension of flexibility, appropriateness, accuracy, fluency, coherence, and breadth by $\mathrm{F}$ test, which shows the sample is relatively concentrated with homogeneity of variance; therefore, ANOVA can be performed.

As is shown in Table 4, there are significant differences $(P<0.01)$ in five dimensions (flexibility, appropriateness, fluency, consistency, and accuracy) among students of different genders: the mean of girls which almost come to the statement of CSE level 5 is higher than that of boys, who have more space for 
improvement. But there is no significant difference $(P>0.05)$ in the expression of breadth, girls' is slightly better than that of boys. So, more attention should be paid to boys.

Table 4. Gender differences in oral English ability of college non-English majors

\begin{tabular}{ccccc}
\hline Dimensions & \multicolumn{2}{c}{ Gender $($ mean \pm standard deviation) } & \multirow{2}{*}{ t } & \multirow{2}{*}{ Male $(\mathrm{N}=86)$} \\
\cline { 2 - 3 } & Female $(\mathrm{N}=336)$ & $2.73 \pm 0.71$ & 3.000 & $.003^{* *}$ \\
\hline Flexibility & $2.98 \pm 0.70$ & $2.59 \pm 0.75$ & 2.760 & $.006^{* *}$ \\
Appropriateness & $2.83 \pm 0.72$ & $2.53 \pm 0.69$ & 2.608 & $.009^{* *}$ \\
Fluency & $2.75 \pm 0.68$ & $2.63 \pm 0.69$ & 3.151 & $.002^{* *}$ \\
Coherence & $2.90 \pm 0.70$ & $2.38 \pm 0.64$ & 1.792 & .074 \\
Scope & $2.53 \pm 0.67$ & $2.58 \pm 0.69$ & 3.759 & $.000^{* *}$ \\
Accuracy & $2.88 \pm 0.64$ & & & \\
\hline
\end{tabular}

$P<0.05 * * x<0.01$

Table 5 shows there are significant differences in ability of six dimensions among students of different majors $(P<0.05)$ : the mean of business students is higher than that of arts students whose is higher than that of science students, which means oral expression competency of business students (mean value is 2.91) is closer to CSE level 5, comparing with art students. While science students with a much lower mean (2.64) need to make more efforts. All the participants score the lowest on the breadth and fluency, but business and art students are better than science ones. Attention to the science students is needed.

Table 5. Professional differences in oral English ability of non-major college students

\begin{tabular}{|c|c|c|c|c|c|}
\hline \multirow[t]{2}{*}{ Dimensions } & \multicolumn{3}{|c|}{ Profession (mean \pm standard deviation) } & \multirow[t]{2}{*}{$\mathrm{F}$} & \multirow[t]{2}{*}{$P$} \\
\hline & $\begin{array}{c}\text { Business } \\
(\mathrm{N}=52)\end{array}$ & $\begin{array}{c}\text { Arts } \\
(\mathrm{N}=179)\end{array}$ & $\begin{array}{c}\text { Science } \\
(\mathrm{N}=191)\end{array}$ & & \\
\hline Flexibility & $3.08 \pm 0.74$ & $3.01 \pm 0.70$ & $2.81 \pm 0.70$ & 5.139 & $.006^{* *}$ \\
\hline Appropriateness & $2.82 \pm 0.75$ & $2.90 \pm 0.73$ & $2.66 \pm 0.72$ & 5.186 & .006 ** \\
\hline Fluency & $2.87 \pm 0.71$ & $2.76 \pm 0.68$ & $2.61 \pm 0.68$ & 4.111 & $.017 *$ \\
\hline Coherence & $2.95 \pm 0.75$ & $2.85 \pm 0.65$ & $2.65 \pm 0.66$ & 6.271 & $.002 * *$ \\
\hline Scope & $2.73 \pm 0.75$ & $2.55 \pm 0.67$ & $2.39 \pm 0.61$ & 6.295 & $.002 * *$ \\
\hline Accuracy & $3.01 \pm 0.73$ & $2.90 \pm 0.61$ & $2.69 \pm 0.66$ & 7.02 & $.001 * *$ \\
\hline
\end{tabular}

$P<0.05^{* *} p<0.01$

Table 6 shows there is no significant difference $(P>0.05)$ between different grades on the abilities of six dimensions. The mean of junior students (2.84) is slightly higher than that of sophomores (2.74), indicating that oral expression competency of junior students is slightly better than that of sophomores, but both down to CSE level 5. Whether taking college English courses or not has no obvious promotion on the development of oral English ability. 
Table 6. Grade differences in oral English ability of non-major college students

\begin{tabular}{ccccc}
\hline \multirow{2}{*}{ Dimensions } & \multicolumn{2}{c}{ Grade (average \pm standard deviation) } & $\mathrm{t}$ & \multirow{2}{*}{$P$} \\
\cline { 2 - 3 } & \multicolumn{2}{c}{ Junior $(\mathrm{N}=101)$} & Sophomore $(\mathrm{N}=321)$ & \\
\hline Flexibility & $3.04 \pm 0.66$ & $2.90 \pm 0.72$ & 1.739 & .083 \\
Appropriateness & $2.87 \pm 0.70$ & $2.75 \pm 0.74$ & 1.452 & .147 \\
Fluency & $2.77 \pm 0.67$ & $2.68 \pm 0.70$ & 1.127 & .26 \\
Coherence & $2.92 \pm 0.63$ & $2.81 \pm 0.73$ & 1.453 & .148 \\
Scope & $2.59 \pm 0.66$ & $2.47 \pm 0.67$ & 1.619 & .106 \\
Accuracy & $2.87 \pm 0.63$ & $2.80 \pm 0.67$ & 0.968 & .334 \\
\hline
\end{tabular}

$P<0.05^{* *} p<0.01$

\subsection{Problems of NEM college students' oral expression ability}

Comparing the average value of six dimensions for oral expression ability of the subjects (Figure 1), it shows scope, fluency and appropriateness of oral expression of NEMCS need to be improved urgently; scope of expression (2.5) requires the most attention, followed by fluency (2.70) and appropriateness (2.78). According to the data in Figure 2, Figure 3 and Figure 4, the group in need of urgent improvement of scope is the female students of science sophomore (mean value: 2.57, 2.47, 2.39, respectively), while the group in need of urgent improvement of both fluency and appropriateness is the male students of science sophomore (mean value: 2.57, 2.68, 2.61, respectively). In general, the oral English ability of non-English majors from the second-tier universities has not reached CSE level 5; flexibility, accuracy and consistency of oral expression almost reach the level, while scope, fluency and appropriateness are desperately to be improved.

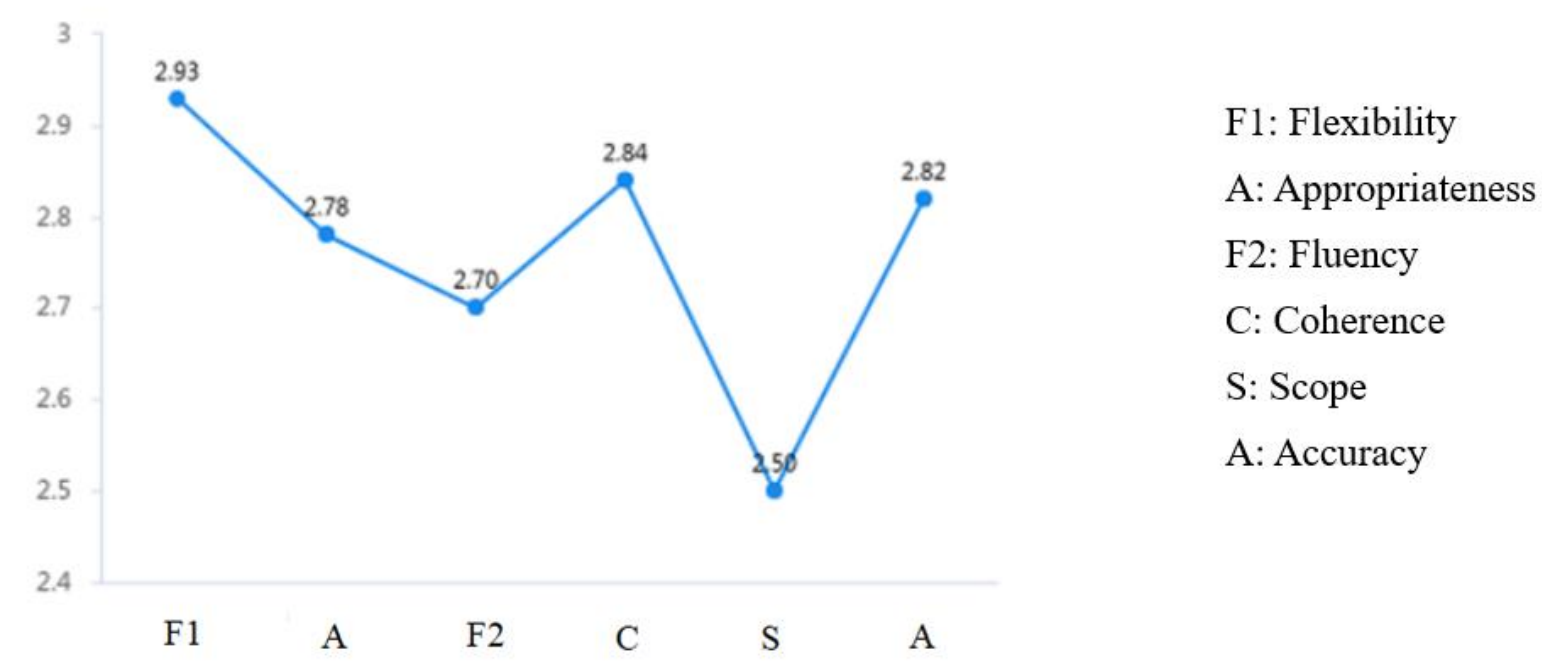

Figure 1. Comparison of dimensional averages 


\section{Female}

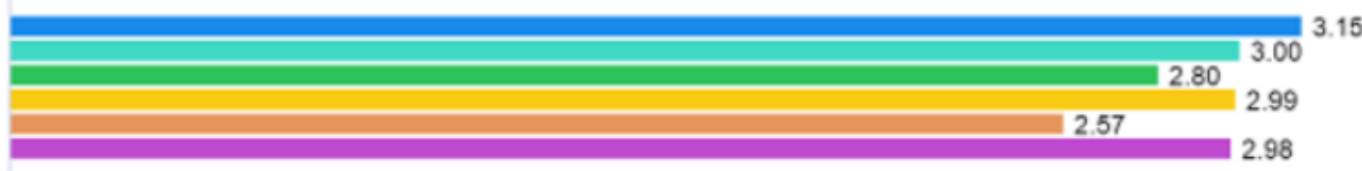

Male

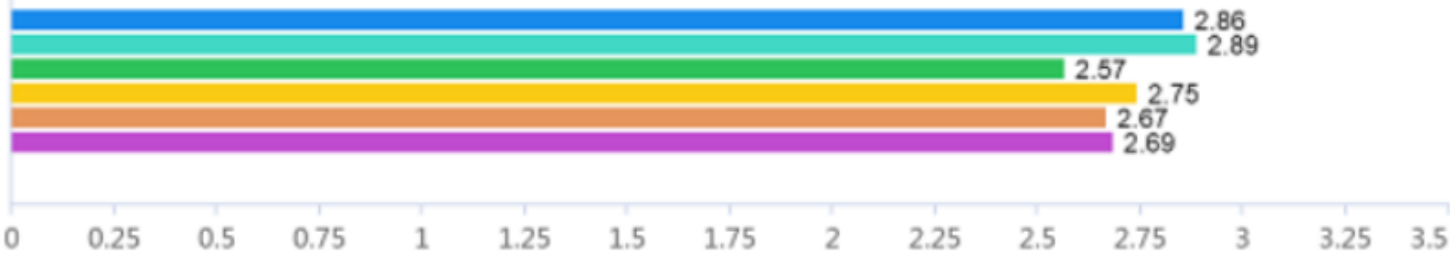

- F1 $\odot \mathrm{A} \bullet \mathrm{F} 2 \ominus \mathrm{C} \bullet \mathrm{S} \bullet \mathrm{A}$

Figure 2. Comparison of different genders on six dimensions

Junior

Sophomore
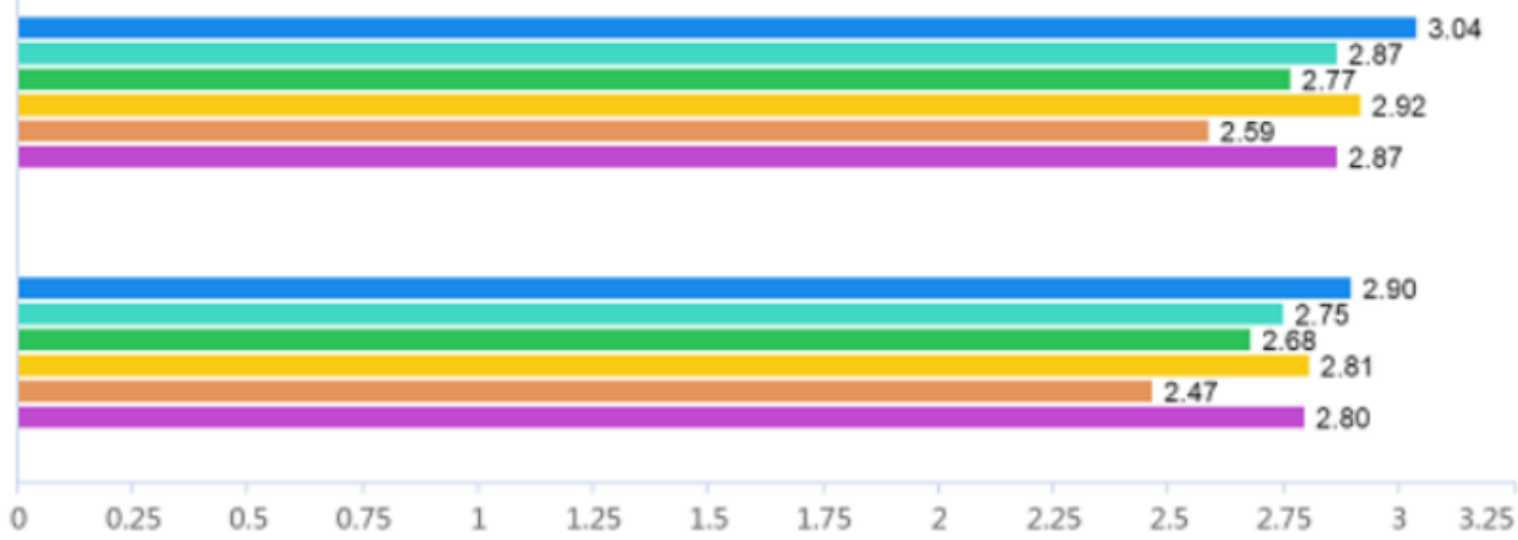

- F1 $\odot \mathrm{A} \odot \mathrm{F} 2 \odot \mathrm{C} \odot \mathrm{S} \odot \mathrm{A}$

Figure 3. Comparison of different grades on six dimensions

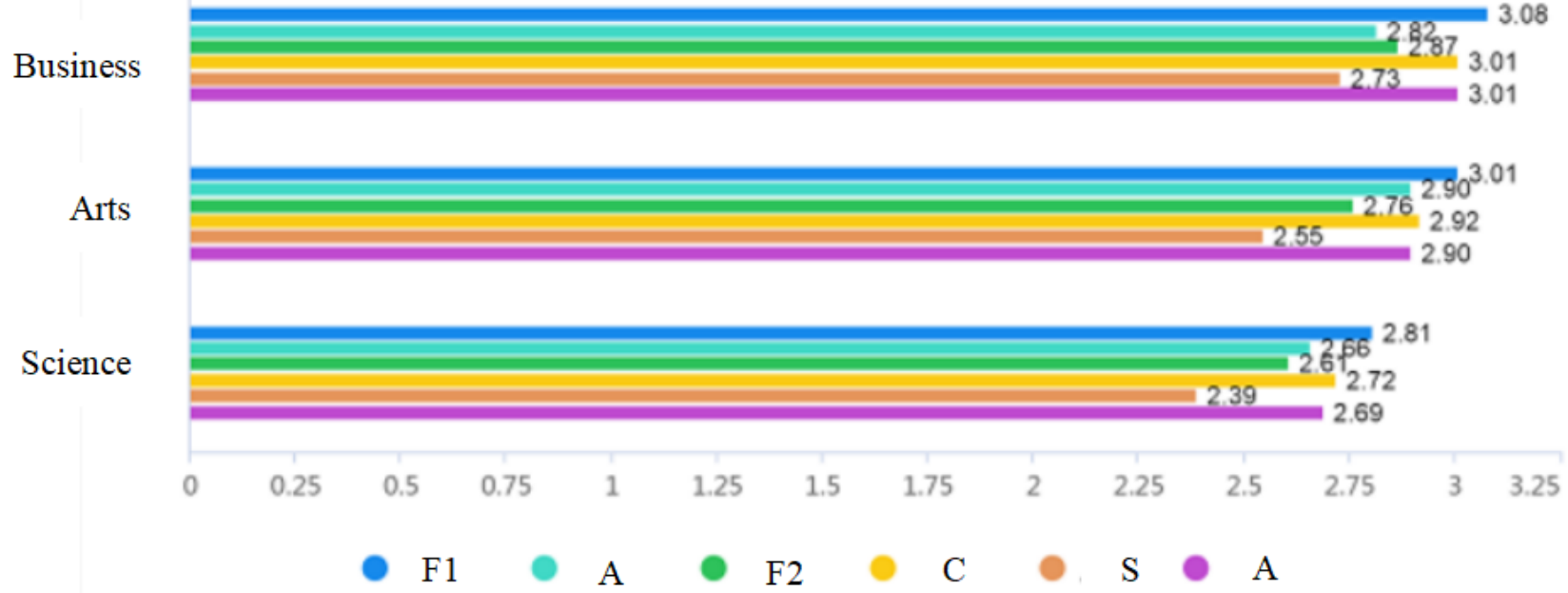

Figure 4. Comparison of different specialties on six dimensions 


\subsubsection{Flexibility of oral expression}

As shown in Table 7, the mean value of flexibility dimension factors is relatively stable, and the total average of all factors (2.931) is close to the mean score (3.0), indicating that participants are at an average level in flexibility of oral expression. The standard deviation (>0.800) indicates there is difference between students. Among the six factors (in Table 4), the score of "being able to solve communication difficulties through inquiry and body language" (3.156) is slightly higher than the average (3.0), which shows in the discussion of familiar topics, participants can adopt appropriate expression strategies to assist communication. For example, they can check whether listeners have understood their talk by asking followup questions and confirm whether their utterance has been understood; can make accurate use of non-verbal cues such as body language in accordance with the situation and communicative needs; can solve difficulties in communication and initiate, continue as well as end conversations naturally.

Table 7. Characteristics of language flexibility of non-professional college students

\begin{tabular}{|c|c|c|c|c|c|c|c|}
\hline & Discussion on familiar topics & $\mathrm{N}$ & $\begin{array}{l}\text { Minimum } \\
\text { value }\end{array}$ & $\begin{array}{l}\text { Maximum } \\
\text { value }\end{array}$ & Average & $\begin{array}{l}\text { Standard } \\
\text { deviation }\end{array}$ & Total average \\
\hline & $\begin{array}{l}\text { Can take appropriate measures } \\
\text { (e.g., inquiry, body language) }\end{array}$ & 422 & 1.000 & 5.000 & 3.156 & .882 & \\
\hline $\mathbf{F}$ & to solve communication & & & & & & \\
\hline $\mathbf{L}$ & difficulties & & & & & & 2.931 \\
\hline $\begin{array}{l}\mathbf{E} \\
\mathbf{X}\end{array}$ & $\begin{array}{l}\text { Can naturally initiate a } \\
\text { conversation }\end{array}$ & 422 & 1.000 & 5.000 & 2.865 & .846 & \\
\hline $\begin{array}{l}\text { I } \\
\text { B }\end{array}$ & $\begin{array}{l}\text { Can naturally participate in the } \\
\text { conversation }\end{array}$ & 422 & 1.000 & 5.000 & 2.891 & .876 & \\
\hline I & Can naturally keep talking & 422 & 1.000 & 5.000 & 2.903 & .849 & \\
\hline L & $\begin{array}{l}\text { Can end the conversation } \\
\text { naturally }\end{array}$ & 422 & 1.000 & 5.000 & 2.936 & .848 & \\
\hline $\begin{array}{l}\mathbf{T} \\
\mathbf{Y}\end{array}$ & $\begin{array}{l}\text { Can transfer the conversation } \\
\text { naturally }\end{array}$ & 422 & 1.000 & 5.000 & 2.836 & .835 & \\
\hline
\end{tabular}

\subsubsection{Accuracy and coherence of oral expression}

Table 8 shows participants' almost have correct pronunciation (2.896) and natural intonation (2.775) in daily English communication, but they are weak at the use of phonological knowledge in oral expression such as stress, liaison, reduced voice and loss of plosion (2.611). Vocabulary competence (2.846) is slightly higher than that of use of sentence structures (2.784), but they are easy to make mistakes in verb tense in oral expression (2.796). They almost can clearly and orderly use simple conjunctions to link phrases and sentences (2.905) as well as transitional sentences to organize discourse (2.934), but there are some difficulties in achieving semantic coherence through sentence transformation in oral expression (2.664) due to the lack of textual knowledge and single cohesive devices. 
Table 8. Characteristics of accuracy and coherence of language expression on non-major college students

\begin{tabular}{|c|c|c|c|c|c|c|c|}
\hline & $\begin{array}{c}\text { Discussion on familiar } \\
\text { topics }\end{array}$ & $\mathrm{N}$ & $\begin{array}{l}\text { Minimum } \\
\text { value }\end{array}$ & $\begin{array}{l}\text { Maximum } \\
\text { value }\end{array}$ & Average & $\begin{array}{l}\text { Standard } \\
\text { deviation }\end{array}$ & Total average \\
\hline & $\begin{array}{l}\text { Can correctly read } \\
\text { words }\end{array}$ & 422 & 1.000 & 5.000 & 2.896 & .911 & \multirow{7}{*}{2.819} \\
\hline $\begin{array}{l}\mathrm{A} \\
\mathrm{C} \\
\mathrm{C}\end{array}$ & $\begin{array}{l}\text { Can appropriately use } \\
\text { stressed, liaison, } \\
\text { reduced voice and loss } \\
\text { of plosion }\end{array}$ & 422 & 1.000 & 5.000 & 2.611 & .856 & \\
\hline $\mathbf{U}$ & Natural intonation & 422 & 1.000 & 5.000 & 2.775 & .890 & \\
\hline $\begin{array}{l}\mathbf{R} \\
\mathbf{A} \\
\mathbf{C}\end{array}$ & $\begin{array}{l}\text { Can appropriately use } \\
\text { learned } \\
\text { (phrases) }\end{array}$ & 422 & 1.000 & 5.000 & 2.846 & .862 & \\
\hline \multirow[t]{3}{*}{$\mathbf{Y}$} & $\begin{array}{l}\text { Can appropriately use } \\
\text { the acquired English } \\
\text { sentence patterns }\end{array}$ & 422 & 1.000 & 5.000 & 2.784 & .857 & \\
\hline & $\begin{array}{l}\text { Can use the learned } \\
\text { tenses correctly }\end{array}$ & 422 & 1.000 & 5.000 & 2.796 & .839 & \\
\hline & $\begin{array}{l}\text { Can correctly use nouns } \\
\text { in plural }\end{array}$ & 422 & 1.000 & 5.000 & 3.024 & .872 & \\
\hline $\mathbf{C}$ & $\begin{array}{l}\text { Can use simple } \\
\text { conjunctions to connect }\end{array}$ & 422 & 1.000 & 5.000 & 2.905 & .945 & \\
\hline $\mathbf{O}$ & phrases or sentences & & & & & & 2.841 \\
\hline $\begin{array}{l}\mathbf{H} \\
\mathbf{E} \\
\mathbf{R}\end{array}$ & $\begin{array}{l}\text { Can use transitional } \\
\text { statements to organize } \\
\text { discourse }\end{array}$ & 422 & 1.000 & 5.000 & 2.934 & .915 & \\
\hline $\begin{array}{l}\mathbf{E} \\
\mathbf{N} \\
\mathbf{C}\end{array}$ & $\begin{array}{l}\text { Can alter sentence } \\
\text { patterns to achieve } \\
\text { semantic coherence }\end{array}$ & 422 & 1.000 & 5.000 & 2.664 & .833 & \\
\hline $\mathbf{E}$ & $\begin{array}{l}\text { Can be clear and } \\
\text { organized }\end{array}$ & 422 & 1.000 & 5.000 & 2.860 & .802 & \\
\hline
\end{tabular}

\subsubsection{Scope of oral expression}

Table 9 shows the total mean of scope for oral expression (2.499) is much lower than the average score (3.0), which is the lowest among six dimensions. It can be seen that participants are seriously deficient in the application of highly complex sentence structures (2.509) and vocabulary (2.448) in oral expression. It is difficult for them whether simple sentence pattern (2.455) or complex (2.509), actually. Vocabulary learned in College English is poorly absorbed and not used properly, and participants are not good at using relevant words and phrases to discuss familiar topics (2.581), indicating that oral expression in daily communication mainly depends on words and phrases learned in primary and secondary schools. Syntactic complexity, especially the understanding and application of long sentences, is the weakest part of NEM college students among all six dimensions for oral expression. The low use frequency of complex vocabulary acquired in College English (2.448) suggests effectiveness of College English teaching deserves great attention of both students and teachers. 
Table 9. Characteristics of language expression breadth of non-professional college students

\begin{tabular}{|c|c|c|c|c|c|c|c|}
\hline & $\begin{array}{c}\text { Discussion on familiar } \\
\text { topics }\end{array}$ & $\mathrm{N}$ & $\begin{array}{l}\text { Minimum } \\
\text { value }\end{array}$ & $\begin{array}{l}\text { Maximum } \\
\text { value }\end{array}$ & Average & $\begin{array}{l}\text { Standard } \\
\text { deviation }\end{array}$ & Total average \\
\hline & $\begin{array}{l}\text { Can express opinions in } \\
\text { simple English sentence }\end{array}$ & 422 & 1.000 & 5.000 & 2.455 & .814 & \multirow{6}{*}{2.499} \\
\hline $\mathbf{S}$ & patterns & & & & & & \\
\hline $\begin{array}{l}\text { C } \\
\text { O }\end{array}$ & $\begin{array}{l}\text { Can use different related } \\
\text { vocabulary }\end{array}$ & 422 & 1.000 & 5.000 & 2.581 & .796 & \\
\hline $\mathbf{P}$ & Can use the words I & 422 & 1.000 & 5.000 & 2.448 & .771 & \\
\hline \multirow[t]{2}{*}{$\mathbf{E}$} & $\begin{array}{l}\text { learned in college } \\
\text { (English) }\end{array}$ & & & & & & \\
\hline & $\begin{array}{l}\text { Can use clauses to express } \\
\text { opinions }\end{array}$ & 422 & 1.000 & 5.000 & 2.509 & .803 & \\
\hline
\end{tabular}

\subsubsection{Fluency and appropriateness of oral expression}

Table 10 shows the mean value of each factor of fluency is low (2.705). When discussing familiar topics, participants can almost pronounce the words fluently (2.763) but require some pause time (2.777) and some time for self-correction of errors (2.768). It is difficult for them to communicate fluently for a long time (2.600) without a certain amount of language repetition (2.616). The data from appropriateness factors analysis show that the subjects can almost use appropriate vocabulary to express politeness on specific occasions (2.827) and make simple communication in accordance with specific context (2.810), but there are certain difficulties in the proper use of language forms to express purposes and intentions (2.699), which shows language users lack of sociolinguistics knowledge and pragmatic functional knowledge, who cannot apply the knowledge to align linguistic forms with their corresponding intentions by identifying and selecting appropriate discourse to achieve their communicative purpose. Pragmatic ability is worrying.

\subsection{Controlling factors}

To further understand the contributing factors of students' oral expression ability, 20 participants and 8 teachers were interviewed. The participants were randomly classified into two groups, 10 for each, and 30 minutes together. The interview mainly focuses on three aspects: (i) students' attitude, self-assessment and expectations to oral English learning; (ii) regular practice ways and weekly practice time; (iii) the common difficulties when expressing opinion in English. The findings were concluded as follows:

(1) Most students have positive understanding for oral English learning.

93\% of them think spoken English is very important and want to improve it. Only $11 \%$ think they can speak English well, $25 \%$ often speak actively, while less than $10 \%$ actively participate in oral English activities (including CET-4 and CET-6 oral tests). This is because of weak oral expression and unable to do what they hope; less organization of oral expression activities and seldom practice in large class teaching. Some lack self-confidence, afraid of being laughed at for poor English, or is not interested in English. 45\% expect to take oral English as selective courses in third and fourth year.

(2) Students lack systematic phonological knowledge and have insufficient practice.

About $50 \%$ of the respondents practice English by mobile APP, but less than one hour a week; $25 \%$ practice through online audio and video; $20 \%$ practice by reciting and talking to themselves. Only 5\% communicate in English with overseas students and Chinese friends on campus, mainly based on one-way input, and rare interactions, and serious time-shortage. It is consistent with the results of Jia 
and Zheng on the key factors affecting the oral English ability of college freshmen ${ }^{[45]}$. Enough time is needed for the development of foreign language competence ${ }^{[46]}$, and some experts suggest 150 200 hours of learning should be added from the lower level to the higher level ${ }^{[1]}$. College students in the new era share more online resources based on AI, with abundant resources and convenient conditions for oral English learning and practice. But lack of systematic phonological knowledge affects autonomous learning of spoken language based on artificial intelligence; traditional way of assessment leads to low practice motivation; delayed supervision makes it difficult for students to keep up.

(3) Low efficiency of classroom teaching and insufficient internalization of language knowledge.

$90 \%$ of the participants think inadequate of lexical chunks and sentence structures prevents the richness of language use. But light emphasis on reading and writing and delayed consolidation of language knowledge, less reading and accumulation of lexical chunks as well as the expression of opinions with the thinking of mother tongue are the hidden causes on the effectiveness of language learning.

Table 10. Characteristics of language fluency and appropriateness in non-professional college students

\begin{tabular}{|c|c|c|c|c|c|c|c|}
\hline & $\begin{array}{c}\text { Discussion on familiar } \\
\text { topics }\end{array}$ & $\mathrm{N}$ & $\begin{array}{l}\text { Minimum } \\
\text { value }\end{array}$ & $\begin{array}{c}\text { Maximum } \\
\text { value }\end{array}$ & Average & $\begin{array}{l}\text { Standard } \\
\text { deviation }\end{array}$ & Total average \\
\hline $\mathbf{F}$ & $\begin{array}{l}\text { Have a shorter pause in } \\
\text { communication }\end{array}$ & 422 & 1.000 & 5.000 & 2.777 & .911 & \\
\hline $\mathbf{L}$ & & & & & & & 2.705 \\
\hline $\begin{array}{l}\mathbf{U} \\
\mathbf{E}\end{array}$ & $\begin{array}{l}\text { Can hold a longer time } \\
\text { conversation }\end{array}$ & 422 & 1.000 & 5.000 & 2.600 & .832 & \\
\hline $\begin{array}{l}\mathbf{N} \\
\mathbf{C}\end{array}$ & $\begin{array}{l}\text { Smooth word } \\
\text { pronunciation }\end{array}$ & 422 & 1.000 & 5.000 & 2.763 & .870 & \\
\hline $\mathbf{Y}$ & $\begin{array}{l}\text { Less self-revised } \\
\text { interventions }\end{array}$ & 422 & 1.000 & 5.000 & 2.768 & .865 & \\
\hline & $\begin{array}{l}\text { Seldom repeat in daily } \\
\text { communication }\end{array}$ & 422 & 1.000 & 5.000 & 2.616 & .773 & \\
\hline $\begin{array}{l}\mathbf{A} \\
\mathbf{P}\end{array}$ & $\begin{array}{l}\text { Can use appropriate } \\
\text { language forms }\end{array}$ & 422 & 1.000 & 5.000 & 2.699 & .837 & \\
\hline $\begin{array}{l}\mathbf{P} \\
\mathbf{R}\end{array}$ & $\begin{array}{l}\text { according to different } \\
\text { circumstances }\end{array}$ & & & & & & 2.779 \\
\hline O & & & & & & & \\
\hline $\begin{array}{l}\mathbf{P} \\
\mathbf{R} \\
\mathbf{I}\end{array}$ & $\begin{array}{l}\text { Can use simple language } \\
\text { to reply to different } \\
\text { circumstances }\end{array}$ & 422 & 1.000 & 5.000 & 2.810 & .873 & \\
\hline $\begin{array}{l}\mathbf{A} \\
\mathbf{T} \\
\mathbf{E} \\
\mathbf{N} \\
\mathbf{E} \\
\mathbf{S} \\
\mathbf{S}\end{array}$ & $\begin{array}{l}\text { Can use polite words } \\
\text { appropriately in } \\
\text { communication }\end{array}$ & 422 & 1.000 & 5.000 & 2.827 & .875 & \\
\hline
\end{tabular}


(4) Limited classroom oral activities and low coverage rate on students.

$90 \%$ of teachers attach importance to the development of students' oral expression competence and their own development. But teachers pay more attention to reading and writing in class because of students diversity for oral English and heavy teaching tasks. Activities of oral practice in class are limited and mainly based on the materials from textbook, with occasional supplementation and less interesting, which result in low coverage rate on students.

\section{Conclusion}

Based on the scale for oral expression of the CSE level 5, this study mainly explored the current situation for oral expression competence of NEMCS (Second and Third year) from second-tier universities, and the differences between different majors, genders and grades through both questionnaire and interview, limiting factors are discussed. SPSS 19.0 was used for statistics analysis.

The oral expression ability of NEMCS from second-tier universities has not come to the CSE level 5. There are significant differences between genders and majors in students' oral expression ability: girls' performance is better than that of boys; business students are better than arts students, and arts students are better than science students; junior students' oral expression ability is slightly better than that of sophomore students, but there is no significant difference.

Among the six dimensions of oral English ability, the flexibility, accuracy and consistency almost reach the level of CSE 5. But the use of phonological knowledge is far from it, especially in appropriate use of stressed, liaison, reduced voice and loss of plosion in daily communication. Incorrect verb tenses and poor use of cohesive devices are common. Fluency and appropriateness barely meet the standard. But long pauses, times of self-correction and language repetition are regular, language application cannot be consistent with the specific context. Richness of language is not up to standard. Complex sentence structures and advanced vocabulary use are seriously inadequate, and knowledge acquired in college English is in low absorption.

The main influencing factors are as follows: less optimum English learning environment leading to less learning enthusiasm and low self-practice; lack of phonological knowledge and insufficient internalization of language; single-classroom teaching model and not enough practical oral communication; less focus on oral practice and training and less practice opportunities; non-specific teaching evaluation, and less guidance and supervision.

It is urgent to improve oral English teaching, and complexity, fluency and appropriateness of oral expression are the key points for the improvement of oral communication ability of non-English majors. Teachers can use CSE-SS to evaluate students' spoken language competence and clarify the target of oral language teaching ${ }^{[5]}$. Based on the real needs of students, we need to enrich teaching means, transform teaching methods, optimize curriculum setting and create a smart, effective classroom, help students use the scale for self-evaluation and establish their learning goals ${ }^{[1]}$, pay attention to the combination of learning and application, promote application by learning and promote learning by evaluation ${ }^{[47]}$, play the intermediary role of teachers, take production as the driving force, make scientific evaluation, guide students to selectively transform and absorb, and achieve the targets efficiently so as to improve the effectiveness of oral English classroom teaching as well as students' oral English practical ability, and promote the application and improvement of the scale.

\section{Acknowledgments}

This study was financially supported by the Project "Research on Peer Education in College English Classroom Reconstruction" (GD18WZX34) and "A Study of Chinese SBUs from the Perspective of Ritual 
Theory of Interpersonal Relations" (GD17WXZ19) supported by Guangdong Philosophy and Social Science Foundation.

\section{Disclosure statement}

The authors declare no conflict of interest.

\section{References}

[1] Liu J, 2017, Chinese English Ability Scale and English Learning. Foreign Languages in China, 2017(6): 4-11.

[2] Jin Y, Jie W, 2020, Study on the Application and Effect of Language Ability Scale: Taking CSE Oral Scale as an Example. Foreign Language World, 2020(3): 52-60.

[3] Liu J, Peng C, 2017, Construction of a Scientific Chinese English Competency Scale. Foreign Language World, 2017(2): 2-9.

[4] Wang S, 2018, Application of Chinese English Competency Scale in College English Teaching. Foreign Language Education, 2018(4): 1-4.

[5] Jin Y, Jie W, 2017, Principles and Methods of Developing Oral Scale of Chinese English Competency Scale. Foreign Language World, 2017(2): 10-19.

[6] Wang J, 2013, Study on Task Difficulty of Descriptive Language on Chinese Competence Standard: Taking Intermediate Oral Power Table as an Example. Chinese Teaching in the World, 2013(3): 413423.

[7] Yang H, Zhu Z, Fang X, 2011, Proficiency Descriptive Language Factor Analysis and Competency Classification: A Practical Study on the Establishment of Language Competency Scale. Modern Foreign Languages, 2011(2): 151-161.

[8] Jie W, 2019, Study on the Interface between Oral English Test and Chinese English Proficiency Scale: Taking CET-SET 4 as an Example. Foreign Language World, 2019(1): 71-80.

[9] Wang H, 2020, A Study on the Validity of the Oral Sub-Scale of the Chinese English Competence Scale: A Text-Based Mining Method. Journal of Xi' an Foreign Studies University, 2020(2): 69-74.

[10] Zhang X, Jin Y, 2019, Effect of Scoring Scale on Conjunctive Validity of Oral Examinations: A Perspective of Interactive Conjunctive Theory. Foreign Languages World, 2019(1): 61-70.

[11] Wang L, Zhou D, 2004, Twelve Years of Oral English Studies in My Country: A Review and Current Situation. Foreign Languages, 2004(6): 7-14.

[12] Bygate M, 1987, Speaking, Oxford University Press.

[13] Levelt WJ, 1999, Models of Word Production. Trends in Cognitive Sciences, 3(6): 223-232.

[14] Kormos J, 2011, Task Complexity and Linguistic and Discourse Features of Narrative Writing Performance. Journal of Second Language Writing, 20(2): 148-161.

[15] Bachman LF, 1990, Fundamental Considerations in Language Testing. Oxford University Press, Oxford.

[16] Bachman L, Palmer A, 2010, Language Assessment in Practice. Oxford University Press, Oxford.

[17] Fulcher G, Reiter RM, 2003, Task Difficulty in Speaking Tests. Language Testing, 20(3): 321-344.

[18] Yang H, Zhu Z, Fang X, 2012, A Study on the Common Scale of Chinese Language Competency Levels: A Study on Theory, Methods and Empirical Study. Shanghai Foreign language Education Press, 
Shanghai.

[19] Leather J, 1999, Second Language Speech Research: An Introduction. Language Learning, 1999(1): $1-56$.

[20] Zhan S, Sun Y, 2020, A Review of Oral English Studies in China for 55 Years. Journal of Chongqing Jiaotong University (Social Sciences Edition), 15(01): 123-126.

[21] Wu Q, 2011, Ten Years of Oral English Studies in China: Current Situation and Reflections: Statistical Analysis of Nine Core Journals of Foreign Languages (1999-2009). Journal of Chengdu Normal University, 27(01): 110-114.

[22] Yang R, 2013, Review and Reflection: A Review of Oral English Studies in China (1949-2012): Statistical Analysis Based on 14 Core Journals of Foreign Languages. Journal of Hubei University of Education, 30(11): 21-24.

[23] Liu J, 2010, Study on Multi-level Rasch Model of Scoring Human Effect. Modern Foreign Languages, 33(02): 185-193, 220.

[24] Li Y, Guan D, 2016, Study on the Effects of Rater Training for PETS Speaking Tests with Many-Facet Rasch Model. Foreign Language Learning Theory and Practice, 2016(03): 45-50.

[25] Cai J, Chen J, 2019, Usage-Based Approaches to Research on VACs in English as an L2. Journal of Beijing International Studies University, 41(5): 4-17.

[26] Chen P, 2008, A Study on English Teaching Based on Oral Fluency Theory at Home and Abroad. Foreign Language World, 2008(03): 40-47.

[27] Chen S, Zhu J, 2010, A Web Platform Based on Audioblogs for College Oral English Teaching and Research. Foreign Language World, 2010(1): 65-70.

[28] Li N, Hu W, 2014, ESP Oral English Instructional Design for Non-English Major Graduates Based on Needs Analysis. Foreign Language Education, 2014(03): 52-55.

[29] East M, 2016, Innovation in Rubric Use: Exploring Different Dimensions. Assessing Writing, 30.

[30] Yu H, 2020, Study on the Dynamic Development of Chinese Learners' Oral English Fluency: On the Interaction Relationship between Complexity, Accuracy and Fluency. Foreign Languages World, 2020(02): 81-89.

[31] Wang W, 2016, The Effect of Verbal Correction Feedback: Meta-Analysis of 25 Western Empirical Studies. Foreign Language Teaching and Research, 48(02): 274-286, 321.

[32] Wang H, 2019, A Study on the Structural Equation Model of the Relationship between Learner Factors and Oral English Achievement. Foreign Language Learning Theory and Practice, 2019(04): 17-26.

[33] Xing J, 2019, A Study on the Influence of Task Complexity on Oral Output of Non-English Major Students. Foreign Languages Research, 36(05): 64-69.

[34] Tang W, 2012, An Analysis of Demotivators in Non-English Major College Students' English Learning. Foreign Language Education, 2012(1): 72-77.

[35] Zhang J, 2006, Emotional Attribution of Subject Behavior in Interactive Communication Activities: Investigation and Analysis on the Development of English Oral Ability of Non-English Major College Students. Foreign Language and Foreign Language Teaching, 2006(7): 25-29.

[36] Liu Z, 2009, The Price Strategy of Selling Fried Dough Sticks. Mass Commerce: Venture Edition, 2009(4): 22-23.

[37] Xing J, Luo S, 2015, The Effects of Task Complexity on Chinese Learners' Language Production: A Synthesis and Meta-Analysis. Applied Research on English Language, 4(2): 96-109. 
[38] Skehan P, 2009, Modelling Second Language Performance: Integrating Complexity, Accuracy, Fluency, and Complexity: A Longitudinal Case Study in the Acquisition of Finnish. Applied Linguistics, 31: 532-553.

[39] Crookes G, 1989, Planning and Interlanguage Variation. Studies in Second Language Acquisition, 11(4): 367-383.

[40] Wigglesworth G, 1997, An Investigation of Planning Time and Proficiency Level on Oral Test Discourse. Language Testing, 14(1): 85-106.

[41] Blanche P, Merino BJ, 1989, Self-Assessment of Foreign Language Skills: Implications for Teachers and Researchers. Language Learning, 1989(3): 313-338.

[42] Ross S, 1998, Self-Assessment in Second Language Testing: A Meta-Analysis and Analysis of Experiential Factors. Language Testing, 15(1): 1-20.

[43] Luoma S, 2012, Self-Assessment, in The Encyclopedia of Applied Linguistics. Wiley-Blackwell, New York, 5169-5174.

[44] Liu J, 2002, A Self-Assessment of Students' English Writing Ability. Modern Foreign Languages, 25(3): 241-249.

[45] Jia S, Zheng Y, 2004, An Empirical Analysis of the Factors Affecting College Students' Oral English Ability. Computer-Assisted Foreign Language Education, 2004(10): 26-29.

[46] Bot KD, 2020, A Bilingual Production Model: Levelt's 'Speaking Model' Adapted, The Bilingualism Reader, 384-404.

[47] Wen Q, 2016, Evaluation of Teacher-Student Cooperation: A New Evaluation Form. Foreign Language World, 2016(5): 37-43. 